\title{
Effect of different protein sources on protease activity of northern pike, Esox lucius Linneaus 1758, juvenile
}

\section{Farklı protein kaynaklarının turna, Esox lucius Linneaus 1758, jüvenillerinin proteaz aktivitesi üzerine etkisi}

\author{
Kaya Gökçek $^{1^{*}}$ - Tamás Szabó 2 • Cüneyt Suzer ${ }^{3}$ \\ ${ }^{1}$ Animal Sciences Department, Hatay Mustafa Kemal University, Hatay, Turkey \\ 2 Department of Aquaculture, Szent Istvan University, Gödöllö, Hungary \\ ${ }^{3}$ Ege University Faculty of Fisheries, Department of Aquaculture, İmir Turkey \\ Corresponding author: kayagokcek@yahoo.com
}

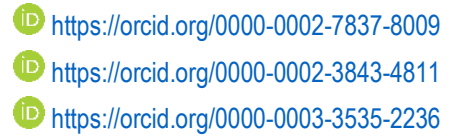

Received date: 30.10 .2019

Accepted date: 29.11.2019

\section{How to cite this paper:}

Gökçek, K., Szabó, T. \& Cüneyt, S. (2020). Effect of different protein sources on protease activity of northern pike, Esox lucius Linneaus 1758, juvenile. Ege Journal of Fisheries and Aquatic Sciences, 37(2), 135-138. DOI: 10.12714/egejfas.37.2.03

\begin{abstract}
The aim of the study is to determine the inhibitory effect of different protein sources on protease activity of Northern pike, $E$. lucius, during larval ontogeny. For this purpose, Northern pike were fed from yolk sac absorption until 21 days after hatching (DAH). At that point, larvae were sampled on 7,14 and $21 \mathrm{DAH}$ days and the activity of enzyme was analyzed in vitro. In the study, two different fish meal, chicken meal, krill meal, corn gluten, soybean protein concentrate, soybean meal and dried distillers grains with solubles were tested. Fish meal-I showed the lowest effect (7.53\%) on 7 DAH larvae. Moreover, chicken meal has the highest inhibitory effect on the proteases in the first week (68.27\%). In the following period (DAH 14), although the inhibition ratio dramatically increased in all ingredients, fish meal-I has still the lowest effect on proteolytic activity (55.66\%). In the same period, the highest effect was obtained from krill $(82.28 \%)$ and chicken meals $(86.73 \%)$, respectively. Then, there was no statistical difference between fish meal-I, fish meal-II and corn gluten in the $21 \mathrm{DAH}$ and relatively lower than the others $(p>0.05)$. Additionally, chicken meal again has the highest effect on juveniles with the ratio $89.27 \%$. As a result, the increase of proteolytic activity was notably increased in 7-14-21 DAH, however, it is concluded that feeding larvae and juveniles with live prey is still suggested to get better result for such a carnivorous species culture.
\end{abstract}

Keywords: Northern pike, protease activity, protein sources, inhibition effect

Öz: Bu çalışmanın amacı, farkı protein kaynaklarının turna balığının larval gelişimi sırasında sindirim enzimlerinden proteaz enzimlerini inhibe edici etkisinin tespit edilmesidir. Bu amaçla, Turna balığı, E. lucius, larvaları yumurtadan çıkıştan itibaren 21. günün sonuna kadar beslenmişlerdir. Bu noktada, besleme yapılan larvalardan 7, 14 ve 21. günlerde örnekler alınarak in vitro enzim aktiviteleri tespit edilmiştir. Çalışmada, protein kaynağı olarak iki farkı balık unu, tavuk unu, krill unu, mısır glüteni, soya protein konsantresi, soya unu ve damıtımış tahıl test edilmiştir. Yedinci günde, en düşük etki balık unu-I grubunda tespit edilmiştir (\% 7,53). Ayrıca, tavuk unu ilk hafta en yüksek durdurucu etkiyi göstermiştir (\% 68,27). Bunu takip eden dönemde (14. gün), tüm hammaddelerin durdurucu etkisi dramatik bir şekilde artmış olsa da, proteolitik aktivite üzerindeki en düşük etki yine balık unu-I grubunda görülmüştür (\% 55,66 ). Aynı dönem içerisinde, en yüksek etki krill ve tavuk ununda tespit edilmiştir (sırasıyla, $\% 82,28$ ve 86,73 ). Ardından, 21. günde ise balık unu-I, balık unu-II ve mısır gluteni arasında herhangi bir istatistiki fark bulunmamıştır ( $p>0.05$ ). Bunun yanında, tavuk unu bu dönemde de enzim aktivitesini durdurucu en yüksek etkiye sahip olmuştur (\% 89,27). Sonuç olarak, $7-14$ ve 21. günlerde proteolitik aktivitenin belirgin artış göstermesi ile birlikte, bu türden karnivor balıkların larva ve juvenil boylarının beslenmesi sırasında canlı yemlerin kullanıımasının daha başarılı gelişim sonuçlarını ortaya koyacağı düşünülmektedir.

Anahtar kelimeler: Turna, proteaz aktivitesi, protein kaynakları, durdurucu etki

\section{INTRODUCTION}

Northern pike is one of the most popular and valuable carnivore freshwater fish species in northern hemisphere. In restaurants and fish markets, the price is almost the same as European catfish (Silurus glanis) and pike perch (Sander lucioperca), in the meantime higher than common carp (Cyprinus carpio) and trout (Oncorhynchus mykiss). Due to being effective bio-meliorator in earthen ponds, it is stocked to polyculture systems to prevent involuntary increase of Prussian carp, Carassius gibelio, especially mid-Europe. The constraining point of its commercial production is high cannibalism ratio which starts at very early larvae stage (Kucska et al., 2006).

The fish feed industry still searches alternative protein sources for fish diets due to the dramatic decrease of natural fish stocks used for fish meal and oil. On the other side, lack of appropriate commercial diets for new candidate specie' is another issue for the potential fish producers. Recently, the plant protein sources used in commercial fish feeds instead of fishmeal to reduce the pressure on natural fish populations causes relatively higher feed conversion ratios. Besides, fish farmers complain for low growth performance when fish are fed 
on these ingredients. It is thought that this situation is probably caused by inadequate amino acid profiles and anti-nutritional factors of plant protein sources (Halver and Hardy, 2002).

In commercial hatcheries, pike larvae are fed with zooplankton collected from ponds for one week and there is a limited period to sell them to the other fish farms (Hazman and Gökçek, 2014). Then they are stocked to the earthen ponds for nursery (Szabo, 2008). To bypass feeding them by live prey, producers has started to feed with trout starter feeds over the last years. Although the food intake and growth performance were acceptable during this period, it is still unclear that the nutritional value met with larvae' requirements or not. Previous results concerning breeding, feeding them in artificial conditions and digestive enzymes were already presented for Northern pike (Kucska et al., 2005; Szabo, 2008; Gökçek et al., 2012; Hazman and Gökçek, 2014). However, there are still some information scarcity such as the effects of commercial feeding protocol on digestive enzyme activities, inhibitory effects on protease activity and bioavailability of different protein sources. In the present work, an in vitro method was carried out to assess the interaction between proteases and different protein sources to make a contribution to development of micro diets for Northern pike.

\section{MATERIAL AND METHODS}

\section{Source of fish and sampling method}

Northern pike larvae were produced from broodstock in captivity in Szeged Fish Farm Kft., Hungary. Routine artificial production procedure was applied for fertilization (Szabo, 2008). After hatching, larvae were transferred to the $350 \mathrm{~L}$ circular tanks in the same hatchery and stocking density was 100 larvae/L. During the experiment, the water temperature was $13 \pm 1^{\circ} \mathrm{C}$. In the study, fish were fed with trout starter diet (56\% CP) (Coppens, Nederland) 8 times per day. One hour after feeding activity, about $500 \mathrm{mg}$ larvae were sampled daily into $3 \mathrm{ml}$ Eppendorf tubes without water and then freeze stored at $-20^{\circ} \mathrm{C}$.

\section{Analysis of total protease activity}

Whole body homogenates of larvae were prepared to get enzyme extracts by centrifugation $\left(12000 \mathrm{~g}, 20 \mathrm{~min}, 4^{\circ} \mathrm{C}\right)$. Casein $\left(10 \mathrm{mg} \mathrm{ml}^{-1}\right)$ was used as substrate and dissolved in 50 $\mathrm{mM}$ Tris-HCl buffer at pH 9 (Walter, 1984). The substrate and enzyme extracts of larvae were incubated at $37^{\circ} \mathrm{C}$ for 1 hour. Then, $500 \mu$ l trichloroacetic acid (TCA) $(12 \%)$ was used to stop the reaction. The mixture was incubated at $4^{\circ} \mathrm{C}$ for 10 minutes and after centrifugation $\left(8000 \mathrm{~g}, 15 \mathrm{~min}, 4^{\circ} \mathrm{C}\right)$ the absorbance was recorded at $280 \mathrm{~nm}$. One unit of enzyme activity was defined as $1 \mu \mathrm{g}$ of tyrosine released per minute. The results were expressed as U/mg tissue (Gökçek et al., 2016). All analyses were studied triplicate.

\section{Determination of inhibition effects of protein sources on proteolytic activity}

A modified in vitro method of Garcia-Carreno (1996) was used to determine inhibition effects of two different fish meal (FM-1 and FM-2), corn gluten (CG), soybean protein concentrate (SPC), dried distillers grains with solubles (DDGS), krill meal (KM), chicken meal (CM) and soybean meal (SM) as protein sources on protease activity of 7-14-21 DAH. The amount of crude protein of ingredients were determined by the Kjeldahl method.

Different feed ingredients and protease enzyme extracts were pre-incubated and the residual activity was measured. The extracts $(20 \mu \mathrm{L})$ were incubated with protein solutions (20 $\mu \mathrm{L})$ in Tris $\mathrm{HCl}$ buffer $(500 \mu \mathrm{L})$ for $60 \mathrm{~min}$ at $25^{\circ} \mathrm{C}(\mathrm{pH} \mathrm{9.0)}$. In the control group, same amount of distilled water was used instead of protein solutions in the mixture. Afterwards, $100 \mu \mathrm{L}$ casein was added and the mixture was incubated for 120 minutes at room temperature. Finally, $500 \mu \mathrm{L}$ TCA $\left(120 \mathrm{gL}^{-1}\right)$ was added to stop reaction and after centrifugation $(8000 \mathrm{~g}, 15$ $\min , 4^{\circ} \mathrm{C}$ ) the absorbance was recorded at $280 \mathrm{~nm}$. TCA was added prior to casein in blanks (Alarcon et al., 1999; Gökçek et al., 2016).

\section{Statistical methods}

Results are given as mean \pm S.D. Levene's test for equality were used prior to comparison of data. A one-way ANOVA, followed by Duncan test was applied for comparisons when significant differences were found at the 0.05 level. Statistical analyses were performed with SPSS 22.0 software (Hazman and Gökçek, 2014).

\section{RESULTS}

Feeding protocol, growth performance and proteolytic activity of sampling days were presented in Figure 1. The protease activities were measured as $271.42 \mathrm{U} / \mathrm{mg}$ tissue on 7 $\mathrm{DAH}, 282.23 \mathrm{U} / \mathrm{mg}$ tissue on $14 \mathrm{DAH}$ and $325.64 \mathrm{U} / \mathrm{mg}$ tissue on 21DAH.

The inhibitory degree of feed ingredients on protease activity are given in Table 1. The minimum inhibitory effect was obtained from FM-I on the $7^{\text {th }}$ day-old larvae. CM has the highest inhibitory effect on the proteases in the first week. In the following period (DAH 14), although the inhibition ratio dramatically increased in all ingredients, FM-I has still the lowest effect on proteolytic activity. In the same period, the highest effect was obtained from KM and CM. There was no statistical difference between FM-I, FM-II and CG in the DAH21 and lower than the others $(p>0.05)$. CM again has the highest effect on juveniles with the ratio. 


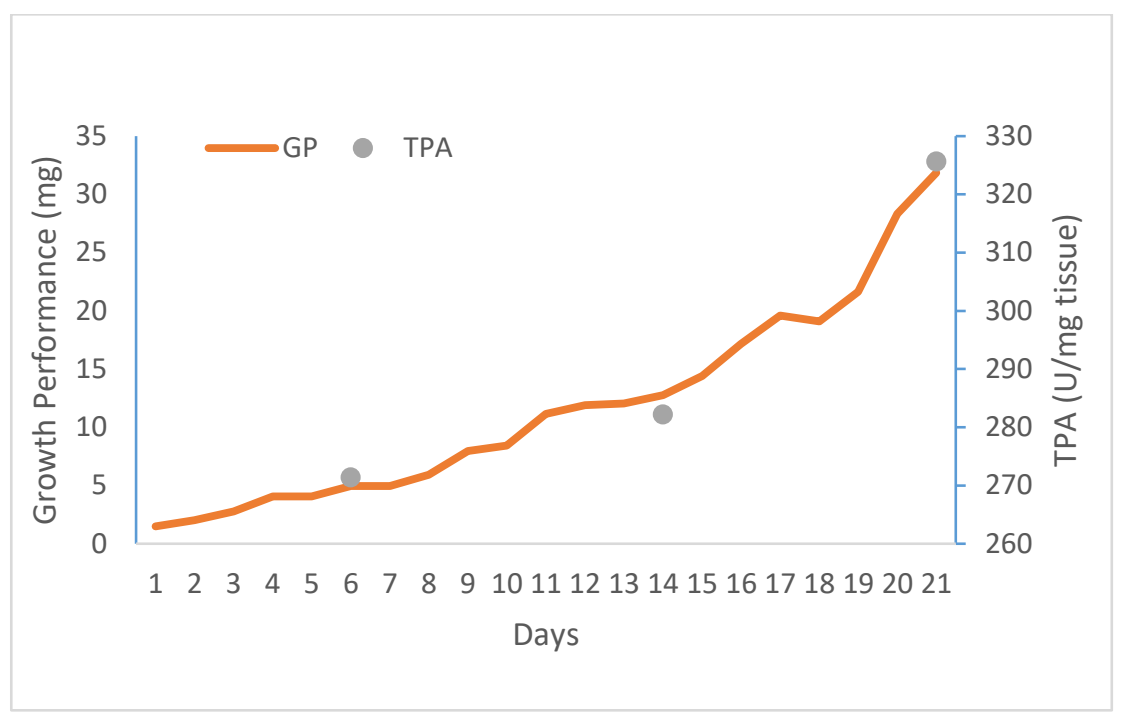

Figure 1. Growth performance and daily changes of total proteolytic activity (TPA)

Table 1. Protein sources and inhibition degree of protease activity

\begin{tabular}{lccc}
\hline PROTEIN SOURCES (\% CP as is) & DAH7 & DAH14 & DAH21 \\
\hline FM-1 (63.25) & $7.53 \pm 0.71^{\mathrm{a}}$ & $55.66 \pm 1.61^{\mathrm{a}}$ & $62.65 \pm 3.77^{\mathrm{a}}$ \\
FM-2 (55.26) & $22.69 \pm 1.35^{\mathrm{b}}$ & $61.01 \pm 2.88^{\mathrm{b}}$ & $67.01 \pm 0.79^{\mathrm{a}}$ \\
CG (57.50) & $32.70 \pm 1.34^{\mathrm{c}}$ & $64.81 \pm 1.42^{\mathrm{b}}$ & $66.41 \pm 2.64^{\mathrm{a}}$ \\
SPC (59.45) & $50.93 \pm 10.15^{\mathrm{de}}$ & $77.90 \pm 6.10^{\mathrm{cd}}$ & $81.56 \pm 0.30^{\mathrm{c}}$ \\
DDGS (31.23) & $60.80 \pm 6.10^{\text {ef }}$ & $80.50 \pm 0.67^{\mathrm{d}}$ & $81.40 \pm 2.33^{\mathrm{c}}$ \\
KM (43.49) & $61.88 \pm 1.16^{\mathrm{e}}$ & $82.28 \pm 6.26^{\mathrm{de}}$ & $84.34 \pm 0,00^{\mathrm{d}}$ \\
CM (53.31) & $68.27 \pm 2.29^{\mathrm{f}}$ & $86.73 \pm 0.28^{\mathrm{e}}$ & $89.27 \pm 1.31^{\mathrm{e}}$ \\
SM (46.16) & $40.62 \pm 4.83^{\mathrm{d}}$ & $70.95 \pm 1.88^{\mathrm{c}}$ & $76.04 \pm 0.71^{\mathrm{b}}$ \\
\hline Means with the same superscripts in the same column are not significantly different $(\mathrm{p}<0.05)$
\end{tabular}

\section{DISCUSSION}

As well known, fish feed production sector focused on developing high quality microdiet feeds to meet with the nutritional requirements of different species since the beginning of the millennium. It could be summarized that a serious distance covered on this purpose. However, there still need to study on it. Sanz et al., (2011) claimed that the total amount of enzymes measured should contain not only the enzyme produced by larvae but also the exogenous originated ones. Therefore, exogenous feeding larvae of carnivore species should be started by live prey at the beginning of the ontogeny of digestive tract. Controversially, according to some other researchers, the secretion of enzymes may be triggered by movement of beaten live prey (Zambanino Infante and Cahu, 2001), but the exogenous enzymes are unnecessary for digestion in the early larval stage (Segner and Rosch, 1998).

Töre et al., (2014) studied the inhibition effect of KM, fish hydrolysate, FM, SM, caviar meal and CG on proteases of 30 DAH northern pike juvenile. Total protease activity was 489.65
$\mathrm{U} / \mathrm{mg}$ tissue in that day. Besides, the fish were fed with Artemia nauplii at first week just after yolk-sac absorbtion. The lowest inhibitory effect was gained from KM $(2.30 \pm 1.26 \%)$, and the highest effect from CG (32.24 $\pm 3.61 \%)$. Gökçek et al., (2016) also tested the inhibitory effects of SPC, SM, CG, blood meal and $\mathrm{FM}$ in 30 DAH Russian sturgeon (Acipencer gueldenstaedtii) juveniles. In that study, the blood meal showed extremely high inhibition effect on proteases $(97.28 \pm 2.31 \%)$, while FM had almost the same ratio as those (15.44 $\pm 5.59 \%)$ reported by Töre et al., (2014). According to Alptekin and Gökçek (2016), although FM and SPC had a similar effect on protease of Siberian sturgeon (A. baerii) juveniles ( $15.34 \pm 3.85$ and $14.45 \pm 1.58 \%$ respectively), SM and blood meal had relatively higher effect on proteases ( 63.33 and $66.67 \pm 4.71 \%$, respectively). Kurt and Gökçek (2018) studied the effects of not only single ingredients but also their dual combinations in 29-day-old starlet (A. ruthenus) juveniles. SPC $(38.57 \pm 10.44 \%)$ and CG $(43.07 \pm 1.72 \%)$ displayed lower effects on the proteases compared with the other ingredients and their dual combinations. Interestingly, FM had higher effect 
than the other ingredients $(57.68 \pm 4.54 \%)$. In the present study, the minimum inhibitory effect obtained from FM-I which has the highest crude protein ratio in among all tested ingredients. Although there was a statistical difference between two different fish meal in DAH14, this difference disappeared by growing larvae in DAH21 ( $p<0.05)$. Also, only CG showed similar effect on proteases as like fish meals in the same period $(p<0.05)$.

On the other hand, from the stand point of enzyme produced by larvae in each period, the protease activity was extremely lower compare to the Töre at al. (2014)'s results. There was a difference between present and former study in terms of feeding method i.e., because previous study tested fish species by maintaining with live prey during early digestive ontogeny. This could have probably led to better development of digestive system compared with maintained on just commercial dry diet. As mentioned before, fish appear to have solely enough and adequate digestive enzyme for live prey in their early life stage, but not for digestion of dry diets.

\section{REFERENCES}

Alarcon, F.J., Moyano, F.J., Diaz, M., Fernandez-Diaz, C. \& Yufera, M. (1999). Optimization of the protein fraction of microcapsules used in feeding of marine fish larvae using in vitro digestibility techniques. Aquaculture Nutrition (5), 107-113. DOI: 10.1046/j.1365-2095.1999.00093.x

Alptekin, C. \& Gökçek, K. (2016). Balık yemlerinde kullanılan farklı protein kaynaklarının Sibirya mersini, Acipencer baerii Brandt 1869, juvenillerinin proteaz aktivitesi üzerine etkileri. Yunus Araştırma Bülteni, (3), 201-207. [in Turkish]

Garcia-Carreno, F.L. (1996). Proteinase inhibitors. Trends Food Scienci Technology, 7, 197-204. DOI: 10.1016/0924-2244(96)10023-6

Gökçek, K., Szabo, T., Alptekin, C., Kurt, R., Töre, Y. \& Urbanyi, B. (2016). A Preliminary Study on Protease Activity of Russian Sturgeon, Acipencer gueldenstaedtii Brandt\&Ratzenburg, 1833, at Early Life Stages. Turkish Journal of Fisheries and Aquatic Sciences, 16, 1025-1029. DOI: 10.4194/1303-2712-v16_4 29

Gökçek, K., Naz, M., Szabo, T. \& Urbanyi, B. (2012). A Preliminary Study on Protease Activity of the Northern Pike (Esox lucius L. 1758) Larvae. Turkish Journal of Fisheries and Aquatic Sciences, 12, 947-950. DOI: 10.4194/1303-2712-v12_4_22

Halver, J.E. \& Hardy, R.W. (2002). Fish Nutrition. Academic Press, USA, 143 $\mathrm{pp}$.

Hazman, B. \& Gökçek, K. (2014). The Effect of Different First Feeds on Proteolitic Activity of the Northern Pike, Esox lucius Linneaus 1758, PostLarvae. Turkish Journal of Fisheries and Aquatic Sciences, 14, 875-878. DOI: 10.4194/1303-2712-v14_4_04

Kucska, B., Müller, T., Sar, J., Bodis, M. \& Bercsenyi, M. (2005). Successful growth of pike fingerlings (Esox lucius L.) on pellet at artifcial condition. Aqauculture, 246, 227-230. DOI: 10.1016/j.aquaculture.2005.01.013
In conclusion, FM-I (63.25\%CP) in the first week; and in the second and third week both fish meals appear to be good protein sources for Northern pike. It is thought that one of the most important points is the amino acid compositions and their possible antagonistic relations have a significance in observed variations between other ingredients. To get a detailed knowledge about the effect of different feed ingredients on enzymatic activity, the determination of the degree of hydrolysis and sequential analysis of protein hydrolysis products should be examined in the future.

\section{ACKNOWLEDGMENTS}

Special thanks to Francisco Javier MOYANO for sharing enzyme analyze methods and for future project ideas. The present work was supported from Mustafa Kemal University Scientific Projects Department with the project number 16792

Kucska, B., Pal, L., Müler, T., Bodis, M., Bartos, A., Wagner, L., Husvth, F. \& Bercsenyi, M. (2006). Changing of fat content and fatty acid profile of reared pike (Esox lucius) fed two different diets. Aquaculture Research, 37, 96-101. DOI: 10.1111/j.1365-2109.2005.01402.x

Kurt, R. \& Gökçek, K. (2018). Farklı Protein Kaynaklarının Çuka Mersini, Acipenser ruthenus Linnaeus 1758, Juvenillerinde Proteaz Aktivitesi Üzerine Etkileri. Limnofish, 4(1), 1-5. DOI: 10.17216/limnofish.325726

Segner, H. \& Rosch, R. (1998). Ontogeny of digestive functions and metabolic functions in Coregonus lauaretus. Archive fur Hydrobiology Special Issues Adv. Limnol., 50, 1-14.

Sanz, A., Llorente, J.L., Furne, M., Ostos-Garrido, V., Carmona, R., Domezain A. \& Hidalgo, M.C. (2011). Digestive enzymes during ontogeny of the sturgeon Acipencer naccarii: intestine and pancreas development. Journal of Appllied Ichthyology., 27, 1139-1146. DOI: 10.1111/j.1439-0426.2011.01864.x

Szabo, T. (2008). Use of Carbopol resin fro carp pitiuitary administration improves the fertilization percentage of northern pike (Esox lucius L.) eggs in commercial hacheries. Hydrobiologia, 601, 91-97. DOI: 10.1007/s10750-007-9269-9

Töre. Y., Gökçek. K., Alptekin. C., Szabo. T. \& Urbanyi. B. (2014). Turna, Esox lucius Linneaus 1758, balığı larvalarının proteaz aktivitesi üzerine ticari yem hammaddelerinin inhibisyon etkilerinin tespiti. In H. Akgün (Eds.). Doğu Anadolu 5. Su Ürünleri Sempozyumu (pp. 228-229). Elazığ, Turkey, 456 pp. [in Turkish]

Walter., H.E. (1984). Proteinases: methods with hemoglobin, casein and azocoll as sub-strates, Methods of Enzymatic Analysis, 5: 270-277.

Zambonino Infante, J.L. \& Cahu, C.L. (2001). Ontogeny of the gastrointestinal tract of marine fish larvae. Comperative Biochemical Physiology. C, 130, 477-487. DOI: 10.1016/S1532-0456(01)00274-5 